\title{
PERANCANGAN LAPORAN PENGONTROLAN KWH LISTRIK MENGGUNAKAN GRAFIK LINE PADA PT PLN (Persero) WILAYAH LAMPUNG CABANG TANJUNG KARANG
}

\author{
Ria Saputri
}

\begin{abstract}
PT PLN (Persero) Wilayah Lampung cabang Tanjung Karang merupakan cabang dari PT PLN (persero) Wilayah Lampung yang bertugas melaksanakan kegiatan perwujudan tenaga listrik, pelayanan pelanggan, pengoperasian dan pemeliharaan pembangkit dan jaringan distribusi tenaga listrik di Wilayah kerjanya secara efisien. Laporan pengontrolan Kwh sangat penting, mengingat listrik adalah salah satu sumber yang sangat dibutuhkan didalam kehidupan masyarakat, namun saat ini laporan pengontrolan Kwh yang dilakukan oleh PT PLN (Persero) Wilayah Lampung cabang Tanjung Karang masih dilakukan semi manual.
\end{abstract}

Keywords:Data flow diagram, entity relationship, grafik line.

\section{PENDAHULUAN}

\subsection{Latar Belakang}

PT PLN (Persero) Wilayah Lampung cabang Tanjung Karang merupakan cabang dari PT PLN (persero) Wilayah Lampung yang bertugas melaksanakan kegiatan perwujudan tenaga listrik, pelayanan pelanggan, pengoperasian dan pemeliharaan pembangkit dan jaringan distribusi tenaga listrik di Wilayah kerjanya. Salah satu kegiatan yang ada di PT PLN (Persero) Wilayah Lampung cabang Tanjung Karang terdapat pencatatan laporan Kwh. Tanpa adanya sistem yang baik, maka kelangsungan usaha akan sulit tercapai, bahkan perusahaan akan mengalami beberapa resiko yang muncul diantaranya : Aktivitas kerja tidak berjalan dengan lancar, kualitas kerja yang dihasilkan tidak sesuai dengan yang diharapkan. Hal ini terjadi karena adanya informasi yang tidak jelas mengenai laporan pengontrolan Kwh dalam aktivitas perusahaan, maka berdasarkan alas an tersebut penulis mengambil judul "Rancangan laporan pengontrolan Kwh listrik menggunakan grafik line pada PT PLN (Persero) Wilayah Lampung cabang Tanjung Karang”.

\subsection{RumusanMasalah}

Berdasarkan latar belakang masalah di atas, maka permasalahan utama yang dapat dirumuskan, yaitu bagaimana sistem yang dijalankan, khususnya pada laporan pengontrolan Kwh dan bagaimana sistem yang tepat untuk rancangan laporan pengontrolan Kwh yang dilakukan pada PT PLN (Persero) Wilayah Lampung cabangTanjungKarang.

\subsection{BatasanMasalah}

Banyaknya kegiatan yang dilakukan di PT PLN (Persero) Wilayah Lampung cabang Tanjung Karang, maka penulis membatasi pembahasan pada "Perancangan Laporan Pengontrolan kwh Listrik menggunakan Grafiklinepada PT PLN (Persero) Wilayah Lampung cabangTanjungKarang”. Pengontrolan kwh dibatasi untuk pelanggan rumahan.

\subsection{Tujuan dan Manfaat Penelitian}

\section{Tujuan Penelitian}

Penelitian ini dilakukan dengan tujuan :

1. Membangun sistem informasi laporan pengontrolan kwh listrik pada PT PLN (Persero) Wilayah Lampung cabang Tanjung Karang untuk meningkatkan kualitas pelayanan terhadap pelanggan.

2. Sistem ini diharapkan dapat Meningkatkan efektifitas dan efisiensi pekerjaan.

\subsection{Manfaat Penelitian}

Manfaat dari penelitian ini adalah: Hasil penelitian ini dapat dijadikan masukkan atau pertimbangan dalam pengembangan sistem informasi perusahaan dan pemanfaatan teknologi sistem informasi yang ada sebelumnya, yang digunakan untuk mendukung effisiensi dalam hal pengolahan data Pembayaran pengiriman paket. Manfaat lain dari hasil penelitian ini dapat digunakan sebagai sarana penerapan ilmu pengetahuan pada dunia kerja.

\subsection{RuangLingkup}

Kegiatan penelitian ini dilakukan pada PT PLN (Persero) Wilayah Lampung cabang Tanjung Karang. Penelitian ini hanya akan membahas bagaimana suatu laporan pengontrolan dapat memberikan informasi yang akurat dan relevan, yang nantinya diharapkan dapat memudahkan petugas dalam mengolah data sehingga dapat 
meningkatkan kinerja PT PLN (Persero) Wilayah Lampung cabang Tanjung Karang. Ruang lingkup kegiatan yang akan dilakukan selama penelitian ini berlangsung secara garis besar adalah :

1. Koordinasi dengan bagian pengolahan data.

2. Perancangan sistem menggunakan ContexDiagram (CD), Data Flow Diagram (DFD) dan Flowchart.

3. Perancangan basis data menggunakanNormalisasidanEntity Relationship Diagram (ERD).

4. Pelaksanaan pembuatan model (prototype)aplikasi sistem menggunakan borland delphi 7.0

5. Penerapan dan uji coba aplikasi secara terpadu.

\section{Metodologi penelitian}

Melakukan penelitian dibutuhkan suatu metodologi. Metodologi adalah kesatuan metodemetode, prosedur-prosedur, konsep pekerjaan, aturan-aturan yang digunakan oleh suatu pengetahuan seni atau disiplin lainya, sedangkan metode adalah suatu cara, teknis sistematis untuk mengerjakan sesuatu.

\subsection{Metode Pengumpulan Data}

Metode penelitian yang digunakan penulis untuk mengumpulkan data dalam penelitian ini yaitu sebagi berikut :

\section{a. Wawancara (Interview)}

Wawancara yang penulis lakukan adalah melalui bagian pelayanan, bagian pengolahan data dan kepegawaian, untuk dapat mengumpulkan informasidan data-data yang diperlukan dalam penelitian ini.

\section{b. Pengamatan (Observation)}

Guna mendukung penelitian ini, penulis juga melakukan pengamatan terhadap laporan pengontrolan kwh secara sistematis terhadap unsurunsur yang butuhkan.

\section{c. TinjauanPustaka (Library Research)}

Metode ini dilakukan dengan cara pengumpulan data melalui sumber-sumber bacaan yang terkait dengan data yang dibutuhkan, sehingga penulis dapat menganalisis data yang akan disusun dalam menunjang proses penelitian.

\subsubsection{Metode Pengembangan Sistem}

Metode yang digunakan dalam pengembangan sistem yaitu dengan siklus klasik/air terjun dengan tahapan-tahapan yang terdiri dari Analisis dan Rekayasa Sistem, Analisis Persyaratan, Perancangan, Coding (Penulisan Program), Pengujian, dan Pemeliharaan, yang ditunjukkan oleh gambar model air terjun di bawah ini :

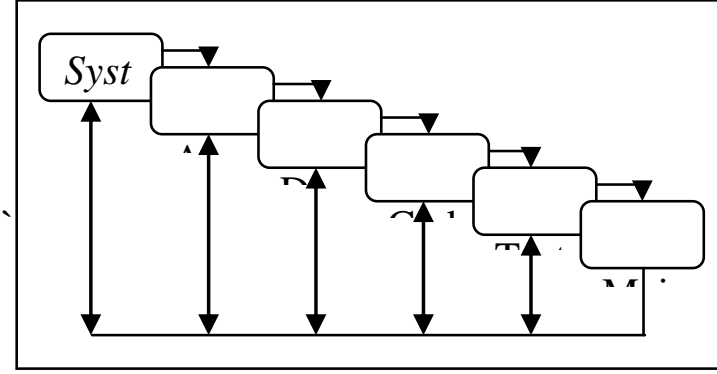

Gambar 1.1 Gambar Model Waterfall

\section{TINJAUAN PUSTAKA}

\subsubsection{Pengertian Sistem}

"Suatu sistem adalah suatu jaringan kerja dari prosedur-prosedur yang saling berhubungan, berkumpul bersama-sama untuk melakukan suatu kegiatan atau untuk menyelesaikan suatu sasaran tertentu”. (HM,Jogiyanto, 1999:1). “Suatu prosedur suatu urut-urutan operasi klerikal (tulis menulis), biasanya melibatkan beberapa orang di dalam satu atau lebih departemen, yang diterapkan untuk menjamin penanganan yang seragam dari transaksitransaksi bisnis yang terjadi”. (HM,Jogiyanto, 1999:1).

\subsubsection{Karakteristik Sistem}

Menurut Jogianto suatu sistem mempunyai karakteristik atau sifat-sifat yang tertentu, yaitu:

a. Komponen-komponen(Components)

Suatu sistem terdiri dari sejumlah komponen yang saling berinteraksi, yang artinya saling bekerjasama membentuk satu kesatuan.

b. Batas Sistem(Boundary)

Batas sistem merupakan daerah yang membatasi antara suatu sistem dengan sistem yang lainnya atau dengan lingkungan luarnya.

\section{c. LingkunganLuarSistem(Environments)}

Lingkungan luar dari suatu sistem adalah apapun di luar batas dari sistem yang mempengaruhi operasi sistem. Lingkungan luar sistem dapat bersifat menguntungkan dan dapat juga bersifat merugikan sistem tersebut.

d. Penghubung(Interface)

Penghubung merupakan media penghubung antara satu subsistem dengan subsistem yang lainnya. 


\section{e. Masukan(Input)}

Masukan adalah energi yang dimasukkan ke dalam sistem. Masukan dapat berupa masukan perawatan (maintenance input) dan masukan sinyal (signal input).

\section{f. $\operatorname{Keluaran}($ Output)}

Keluaran adalah hasil dari energi yang diolah dan diklasifikasikan menjadi keluaran yang berguna dan sisa pembuangan.

g. Pengolah(Process)

Suatu sistem dapat mempunyai suatu bagian pengolah yang akan merubah masukan menjadi keluaran.

h. Sasaran(Objectives)

Suatu sistem pasti mempunyai tujuan (goal) atau sasaran (objective). Kalau suatu sistem tidak mempunyai sasaran, maka operasi sistem tidak akan ada gunanya.

\subsubsection{Komponen Sistem}

Terdapat enam komponen dari sebuah sistem informasi.

a. Blok Masukan(InputBlock)

Input mewakili data yang masuk ke dalam sistem informasi. Input di sini termasuk metode-metode dan media untuk menangkap data yang akan dimasukkan, yang dapat berupa dokumen-dokumen dasar.

b. Blok Model (ModelBlock)

Blok initerdiridarikombinasiprosedur,

logikadan model matematik yang

akanmemanipulasi data input dan data yang

tersimpan di basis data

dengancara yang

sudahtertentuuntukmenghasilkankeluaran yang diinginkan.

c. Blok Keluaran(OutputBlock)

Produk dari sistem informasi adalah keluaran yang merupakan informasi yang berkualitas dan dokumentasi yang berguna untuk semua tingkatan manajemen serta semua pemakai sistem.

d. Blok Teknologi(TechnologyBlock)

Teknologi merupakan "kotak alat" (tool box) dalam sistem informasi. Teknologi digunakan untuk menerima input, menjalankan model, menyimpan dan mengakses data, menghasilkan dan mengirimkan keluaran dan membantu pengendalian dari sistem secara keseluruhan.

e. Blok Basis data (DatabaseBlock)

Basis data merupakan kumpulan dari data yang saling berhubungan satu dengan lainnya, tersimpan di perangkat keras komputer dan digunakan perangkat lunak untuk memanipulasinya. f. Blok Kendali(ControlsBlock)

Banyak hal yang dapat merusak sistem informasi. Beberapa pengendalian perlu dirancang dan diterapkan untuk meyakinkan bahwa hal-hal yang dapat merusak sistem dapat dicegah ataupun bila terlanjur terjadi kesalahan-kesalahan dapat langsung cepat diatasi.

\subsubsection{Definisi Informasi}

"Informasi adalah data yang diolah menjadi bentuk yang lebih berguna dan lebih berarti bagi yang menerimanya". (HM,Jogiyanto, 1999:8). "Suatu organisasi tanpa adanya suatu informasi maka organisasi tersebut tidak bisa berjalan dan tidak bisa beroperas, dengan kata lain sumber informasi adalah data. Data dapat menggambarkan suatu kejadian yang sedang terjadi, di mana data tersebut akan diolah dan diterapkan dalam sistem menjadi input yang berguna dalam suatu sistem". (Kristanto, Andri, 2003).

\subsubsection{Sistem Informasi}

"Sistem Informasi adalah suatu sistem di dalam suatu organisasi yang mempertemukan kebutuhan pengolahan transaksi harian, mendukung operasi, bersifat manajerial dan kegiatan strategi dari suatu organisasi dan menyediakan pihak luar tertentu dengan laporan-laporan yang diperlukan”.

\subsubsection{Pengertian Data}

"Data adalah fakta mengenai objek, orang, dan lain-lain. (data dapat dinyatakan dengan nilai, angka, deretan karakter, atau simbol)". (Kadir,Abdul, 1999:11).

\section{Pengertian Pengolahan Data}

Pemrosesan data mencakup pengumpulan data, mentransformasikan ke dalam informasi dan penyebaran informasi tersebut.

\section{Pengertian Basis Data}

Basisdata (Database) adalah suatu susunan atau kumpulan data operasional lengkap dari suatu organisasi atau perusahaan yang diorganisir atau dikelola dan disimpan secara terintegrasi dengan menggunakan metode tertentu menggunakan komputer sehingga mampu menyediakan informasi optimal yang diperlukan pemakai. Bagan Alir Dokumen (Dokument Flowchart) Bagan Alir Dokumen (Document Flowchart) adalah salah satu alat dan teknik yang digunakan dalam pengembangan sistem informasi, document flowchart merupakan bagan alir yang menunjukkan arus dari laporan dan formulir termasuk tembusannya.

\section{ERD (Entity Relationship Diagram)}


"ERD merupakan notasi grafis dalam pemodelan data konseptual yang mendeskripsikan hubungan antara penyimpanan". (Irmansyah, Faried, 2003). "ERD berfungsi untuk menggambarkan relasi dari dua file atau dua tabel yang dapat digolongkan dalam tiga macam bentuk relasi yaitu, satu-satu, satu banyak, banyakbanyak". (Oetomo, Budi Sutedjo Dharma, 2002)

Diagram Arus Data (Data Flow Diagram)

"Data Flow Diagramadalahsuatu model logika data atau proses yang dibuat untuk menggambarkan dari mana asal data dan kemana tujuan data yang keluar dari sistem, di mana data tersimpan, proses apa yang menghasilkan data tersebutdaninteraksiantara data yang tersimpandan proses yang dikenakanpada data tersebut".

(Kristanto, Andri, 2003:55).

\section{Pengertian Laporan}

Kata Laporan berasal dari kata lapor yang mendapat akhiran an yang mengandung pengertian memberitahukan, mengabarkan, memberikan rencana.

\section{Pengertian Pengontrolan}

Kata Pengontrolan berasal dari kata Kontrol yang mendapat awalan peng dan akhiran an, yang memiliki arti kendali, pengatur, pengendalian.

\section{Pengertian Rancangan}

Kata perancangan berasal dari kata rancang yang mendapat akhiran an yang mengandung arti membuat rancangan.

\section{Pengertian Borland Delphi}

Borland Delphi merupakan bahasa pemrograman, Djoko susilo (2001:1) mengemukakan :Sebuahbahasapemrograman, Development language, aplikasiuntukmembuataplikasi.

Delphidigunakanuntukmembangunaplikasiwindows aplikasigrafis, aplikasi visual, bahkanaplikasijaringan (client/server) danbasis net.

\section{MySQL}

MySQL merupakan Relation Database Mangement Sistem (RDBMS) yang dikembangkan oleh sebuah perusahaan pengembangan perangkat lunak bernama MySQL AB yang bertempat di Swedia. MySQL didistribusikan secara gratis dibawah lisensi GPL (General Public License), dimana setiap orang bebas menggunakan MySQL, namun tidak boleh dijadikan produk turunan yang bersifat closed source atau komersial.

\section{ANALISIS DAN PERANCANGAN SISTEM Obyek yang Diteliti}

Perancangan laporan pengontrolan kwh listrik menggunakan grafik line pada PT PLN (Persero) Wilayah Lampung cabang Tanjung Karang sampai dengan saat ini sudah terkomputerisasi, namun hasil di terima masih kurang efektif dan efisien metode yang digunakan dengan aplikasi microsoft office Metode ini tentunya akan menyita banyak waktu dan ruang penyimpanan karena masih menggunakan lemari arsip untuk menyimpan buktibukti laporan pengontrolan kwh listrik serta pencarian bukti pembayaran apabila terjadi pengaduan dari pengontrolan kwh listrik kepada PT PLN (Persero) Wilayah Lampung cabang Tanjung Karang.

\section{AnalisisSistem Yang Berjalan}

Sistem yang berjalan pada pengontrolan Kwh listrik pada PT PLN (Persero) Wilayah Lampung cabangTanjungKarang dimulai dari Koordinator yang memberikan laporan yang diberikan kepada Verifikator, kemudian Staff Verifikator melakukan Sampling ulang kelapangan dan membuat laporan yang kemudian diberikan kepada Verifikator dan diserahkan kepada Site Manager dan Supervisor untuk diambil keputusan.

\section{AnalisisKebutuhanInformasi}

Analisis kebutuhan adalah prosedur yang dilakukan untuk membuat spesifikasi sistem yang baru atau sistem yang diperbaiki, didalam analisis kebutuhan ini akan dikemukakan metode yang digunakan dalam penelitian ini yaitu mengidentifikasi permasalahan yang terdapat dalam sistem lama dan melakukan metode pengumpulan data dengan teknik wawancara (Interview), pengamatan (observation), tinjauan pustaka(Library Research).

\section{KebutuhanAntarMuka (Interface)}

Kebutuhanantarmuka

yang dibutuhkanolehpemakai (user) didasarkan atas hasil pengumpulan data melalui wawancara dengan pihak-pihak yang terkait, pengamatan, dan tinjauan pustaka.

\section{Dokumen yang digunakan dalam sistem}

Dokumen-dokumen yang digunakan dalam proses pengawasan pembacaan Kwh meter adalah:

\section{DaftarPembacaan Meter (DPM)}

Daftar Pembacaan Meter (DPM) adalah dokumen yang berisi tentang identitas pelanggan, jumlahpemakaianlistrikbulan yang berjalan yang didapatdaripenguranganstand (angka yang tertera 
di meteranlistrik) bulanlalu di

kurangibulanberjalan.

\section{Surat Tugas Sampling}

Surat Tugas Sampling adalah dokumen yang berisi tentang surat perintah untuk melakukan pembacaan ulang Kwh meter pelanggan. Dasar pembuatanya adalah berdasarkan laporan pembacaan Kwh meter per cater yang di buat oleh Verifikator.

\section{Alur Sistem yang Berjalan}

Alur kerja sistem yang berjalan pada proses laporan pengontrolan Kwh listrik pada PT PLN (Persero) Wilayah Lampung cabang Tanjung Karang, dapat dilihat pada keterangan dibawah ini:

1. Berdasarkan hasil pencatatanKwh meter yang di lakukan oleh Cater, Koordinator membuat laporan pembacaan Kwh meter per Cater di buat 2 rangkap yang didistribusikan lembar 1 di berikan kepada Verifikator dan lembar 2 diarsip berdasarkan bulan.

2. Berdasarkan laporan pembacaan Kwh meter per Cater lembar 1, Verifikator melakukan perbandingan dengan pembacaan Kwh meter per Caterbulan lalu, jika terjadi penurunan penjualan Kwh meter maka Verifikator membuat surat tugas untuk melakukan Sampling pembacaan ulang Kwh meter, dibuat 2 rangkap, yang didistribusikan lembar 1 untuk Staff Verifikator sebagai surat tugas lembar 2 diarsip berdasarkan bulan.

3. Berdasarkan surat tugas, Staff Verifikator melakukan sampling ulang pembacaan Kwh meter dan membuat laporan hasil sampling dibuat 2 rangkap, yang didistribusikan lembar 1 kepada Verifikator lembar 2 diarsip berdasarkan bulan.

\section{Perancangan Sistem \\ Diagram Konteks (Context diagram)}

Sistem rancangan laporan pengontrolan pembacaan Kwh listrik menerima data pelanggan, data karyawan, data ujipetik, data cater, data pembanding, sistem menerima data tersebut untuk diolah yang kemudian dibuat laporan. Laporanlaporan tersebut diberikan oleh sistem kepada pimpinan.

Penjelasan dari diagram konteks tersebut dapat digambarkan seperti pada gambar 3.1 sebagai berikut :

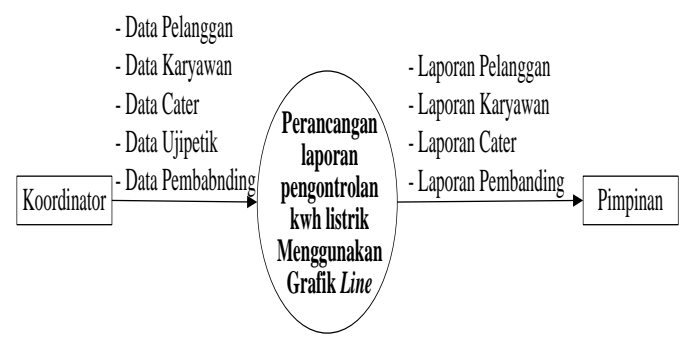

Gambar 3.1 Diagram Konteks Perancangan Laporan Pengontrolan Kwh Listrik Data Flow Diagram (DFD)

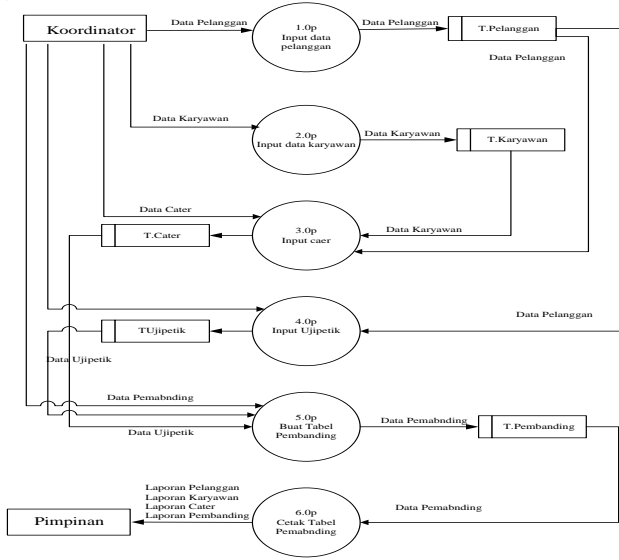

Gambar 3.2 Data Flow Diagram Level 0 PerancanganLaporanPengontrolan Kwh Listrik Entity Relationship Diagram (ERD)

ERD merupakan desain model konseptual database yang memberikan gambaran secara umum kepada pemakai tentang perancangan sistem.

\section{Hubungan Antar Tabel}

Basis data (database)merupakan kumpulandari data yang saling berhubungan satu dengan yang lainnya. Data-data tersebut disimpan dalam sebuah file atau tabel yang memiliki keterangan tertentu, dan apabila direlasikan akan menghasilkan informasi yang kompleks.

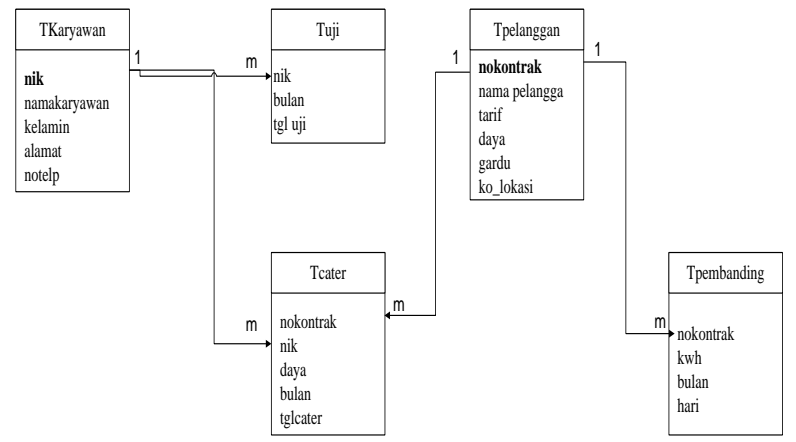

Gambar 3.4 Hubungan Antar Tabel 
Perancangan basis data yang

dibuatmempunyaitujuanuntukmengidentifikasiisiat austrukturdarifield yang

membentuksuatusistemoutput.Perancangan tabel

yang dirancang digunakan sebagai proses

pengolahan data atau menyimpan data.

\section{Struktur Menu Program}

Struktur menu aplikasi yang diusulkan untuk mendukung sistem adalah sebagai berikut :

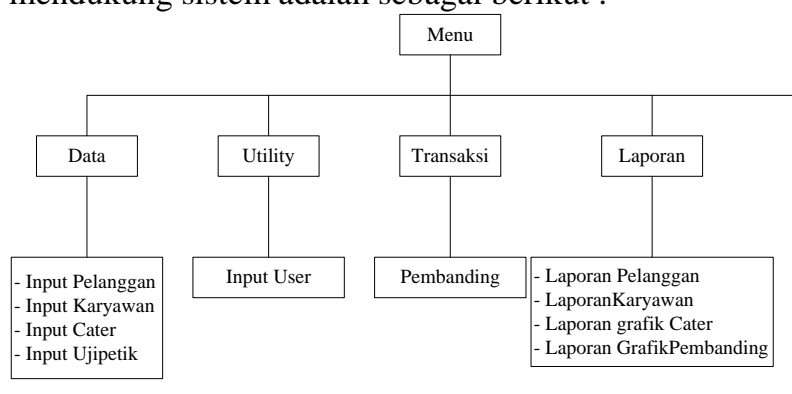

Gambar 3.5 Struktur Menu Program

\section{IMPLEMENTASI \\ SISTEM \\ DAN PEMBAHASAN \\ Implementasi Peranacangan Laporan Pengontrolan Kwh Listrik}

Tahap implementasi adalah tahap rekayasa perangkat keras dan perangkat lunak (hardware dan software enginerring) pada perusahaan atau instansi sejak rancangan sistem komputerisasi yang diajukan telah disetujui oleh perusahaan atau instansi tersebut. Program yang dibuat akan digunakan oleh bagian pengolahan data.

\section{Desain Sistem Baru}

Sebelummenjalankan program aplikasiini, sebaiknya program aplikasisudahter-install denganbaik, untukmempermudahmenjalankan program aplikasisebaiknyadibuaticon ataushortcut pada desktopkomputer. Implementasi perangkat lunak secara garis besar dapat dilihat pada prosedur-parosedur dalam menjalankan program aplikasi pada setiap form.

\section{Tampilan Form Login}

Sebelum masuk ke menu utama (Main Меnu), pengguna sistem (user) harus mengisi Nama Pengguna dan Password terlebih dahulu. Tombol login pada form login berfungsi untuk mengeksekusi login yang telah diisi dan masuk pada menu utama, sedangkan tombol Cancel untuk membatalkan serta keluar dari program. Tampilanform login dapatdilihatpadagambar 4.1 dibawahini.

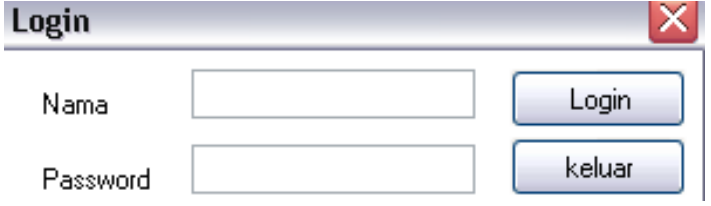

Gambar 4.1 Tampilan Menu Login

\section{Menu Utama}

Pada menu utama program aplikasi terdapat menu data, menu utility, menu transaksi, menu laporan, dan Exit. Tampilan menu utama dapat dilihat pda Exambar

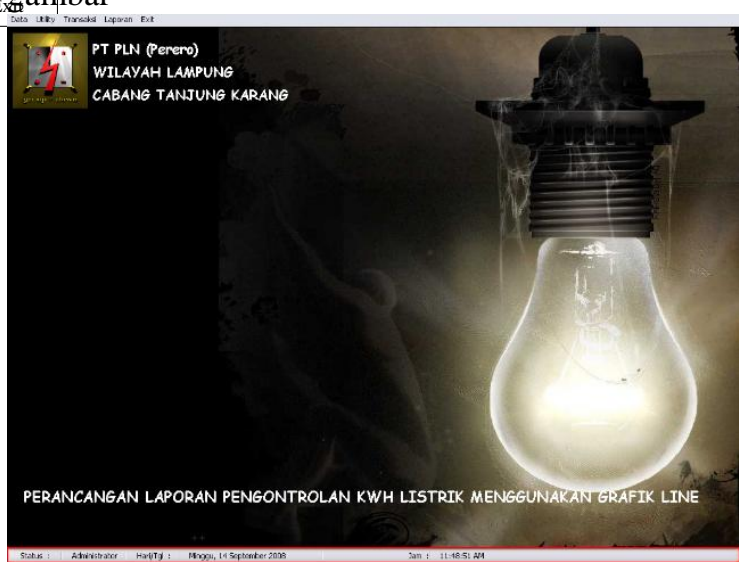

Gambar 4.2 Tampilan Menu Utama

\section{Input Pelanggan}

Form Input Pelanggan berfungsi untuk meng-input pelanggan sesuai dengan tarif yang diinginkan. Proses input pelanggan dilakukan dengan cara meng-inputkan data melalui textbox yang tersedia kemudian dilakukan penyimpanan data-data. Tampilan form dapat dilihat pada gambar 4.5. Fungsi dari masing-masing textbox antara lain :

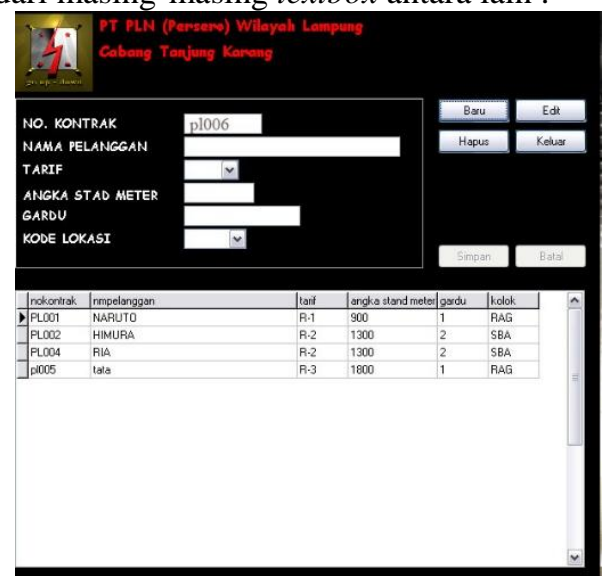

Gambar 4.4 TampilanInput Pelanggan

\section{Input Cater}

Form Input Cater berfungsi untuk meng-input Catat meter sesuai dengan no kontrak. Proses input 
pelanggan dilakukan dengan cara meng-inputkan data melalui textbox yang tersedia kemudian dilakukan penyimpanan data-data. Tampilan form dapat dilihat pada gambar 4.6. Fungsi dari masingmasing textbox antara lain :

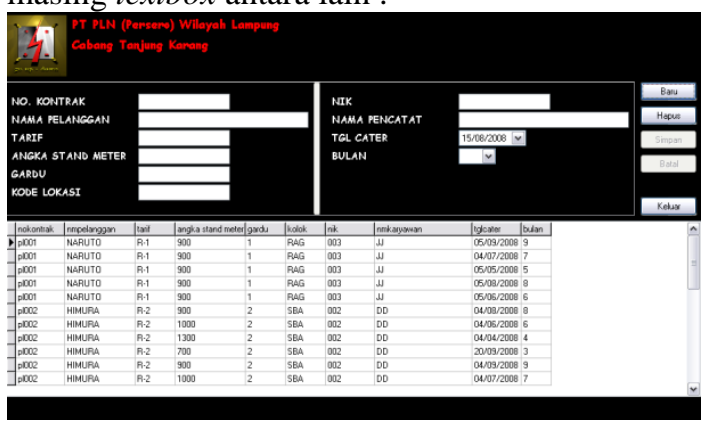

Gambar 4.6 Tampilan Input Cater

Data Pembanding

Forminput data pembandingberfungsiuntukmenginput data-data yang dibutuhkandalampembanding. Proses input data dilakukandengancarameng-input melaluitextbox, option

bottom danDTpickeryangtelahtersediakemudiandilakukanp enyimpanan data-data. Tampilan form dapat dilihat pada gambar 4.8 fungsi dari masing-masing textbox yang ada pada form antara lain:

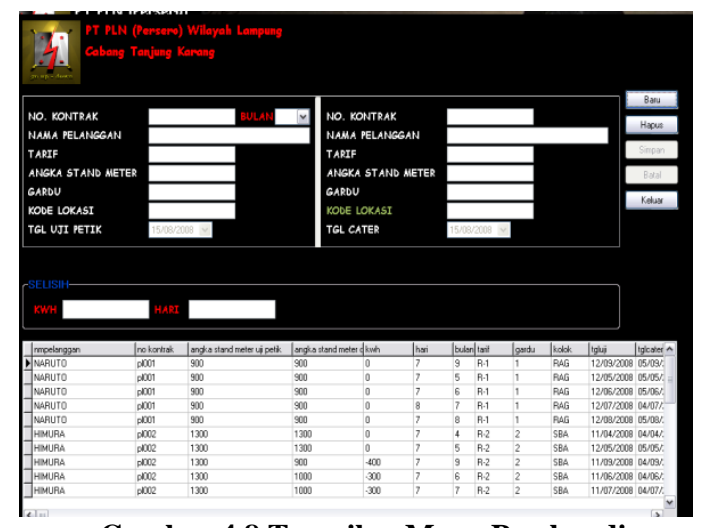

Gambar 4.8 Tampilan Menu Pembanding

\section{Data Pembanding}

Forminput data pembandingberfungsiuntukmenginput data-data yang dibutuhkandalampembanding. Proses input data dilakukandengancarameng-input melaluitextbox, option bottom danDTpickeryangtelahtersediakemudiandilakukanp enyimpanan data-data. Tampilan form dapat dilihat pada gambar 4.8 fungsi dari masing-masing textbox yang ada pada form antara lain:

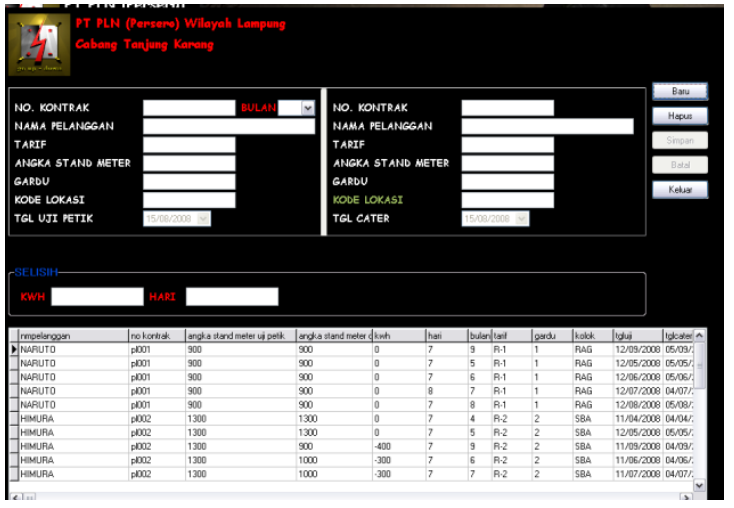

Gambar 4.8 Tampilan Menu Pembanding

\section{SIMPULAN DAN SARAN Simpulan}

Berdasarkan analisa pada hasil penelitian maka penulis dapat mengambil kesimpulan

1. Perancangan Laporan pengontrolan Kwh Listrk masih menggunakan metode semi komputer dengan menggunakan beberapa aplikasi office pada komputer seperti excel dan word. Hal ini mengakibatkan data yang selalu menumpuk dan apabila ada pihak yang membutuhkan data-data pembayaran tersebut maka pencarian data dapat memakan waktu yang cukup lama. Permasalahan-permasalahan dalam laporan pengontrolan kwh listrik seperti, kerangkapan data serta kurangnya keamanan data juga tidak bisa dihindari.

2. Sistem informasi perancangan laporan $\mathrm{kwh}$ listrik memberikan berbagai kemudahan bagi pihak PT. PLN (Persero) Wilayah Lampung cabang Tanjung Karang dalam melakukan proses peng-input-an data, pemrosesan data, pencetakan laporan-laporan dan penyajian informasi yang akurat.

3. Sistem keamanan data yang diberikan ini jauh lebih baik daripada sistem semi dengan adanya nama user, Password.

Saran

Penulis juga memberikan saran-saran yang memungkinkan berguna bagi penelitian ini yaitu

1. Perlunya mengganti sistem laporan perngontrolan kwh listrik pada PT PLN (Persero) Wilayah Lampung cabang Tanjung Karang semi ke sistem yang berbasis client server.

2. Sistem keamanan data yang diberikan ini sebaiknya ditambah lagi bukan sekedar user name dan password tapi pembatasan user dalam pengunaan sistem ini.

\section{DAFTAR PUSTAKA}

1. Departemen Pendidikan Dan Kebudayaan. 1999KamusBesarBahasa Indonesia,.Balai Pustaka. Jakarta. 
2. Drs.BasirBarthos,2000.

ManajemenKearsipan, BumiAksara, Jakarta

3. Fathansyah, 2004. Buku Text KomputerBasia Data. Informatika,

Bandung.

4. Haryanto, Kristanto, 1999. KonsepdanPerancangan Database, Andi Offset, Yogyakarta

5. Hall, James A., 2001. SistemInformasiAkuntansi. Informatika, Yogyakarta

6. JogiyantoH.M,1999. Analisis \&DisainSistemInformasiPendekatan TerstrukturdanPraktekAplikasi. Andi Offset. Jakarta.

7. Kurniadi, Adi, 2001.PemrogramanMicrosoft Visual Basic 6.0. Elexmedia. Komputindo, Jakarta.

8. Mulyadi, 1997. SistemAkuntansi. BadanPenerbitSekolahTinggillmuEkonomi YKPN. Yogyakarta

9. Mulyadi, 2001.

SistemAkuntansi.Salembaempat. Jakarta 